\title{
RESTAURANT DENSITY PREDICTION SYSTEM USING FEED FORWARD NEURAL NETWORK
}

\author{
Muhammad Kurnia Sandi ${ }^{*}$ ) , Anggunmeka Luhur Prasasti ${ }^{2}$, Marisa W. Paryasto ${ }^{3}$ \\ Computer Engineering \\ Telkom University \\ https://telkomuniversity.ac.id \\ muhammadkurniasandi@student.telkomuniversity.ac.id ${ }^{1}$, anggunmeka@telkomuniversity.ac.id ${ }^{2}$ \\ marisaparyasto@telkomuniversity.ac.id ${ }^{3}$
}

$\left(^{*}\right)$ Corresponding Author

\begin{abstract}
Abstrak
Pada zaman sekarang, informasi mengenai suatu hal begitu penting. Tingkat kepercayaan masyarakat modern bergantung pada keterujian suatu informasi. Informasi yang teruji dan akurat akan memberikan dampak yang baik bagi masyarakat banyak. Salah satu informasi yang penting namun sering di lewatkan adalah informasi mengenai kepadatan suatu restoran. Informasi mengenai kepadatan restoran penting untuk diketahui karena dapat mempengaruhi tindakan dari seseorang yang akan mengunjungi restoran tersebut. Informasi ini juga berguna untuk memberi informasi lebih awal agar pengunjung menghindari restoran yang penuh untuk menghindari penyebaran virus Covid-19, dan beberapa hal lainnya. Dengan dibatasinya jam operasi juga jumlah pengunjung restoran, informasi mengenai kepadatan suatu restoran menjadi sangat dibutuhkan. Tidak adanya informasi kepadatan restoran menjadi masalah utama pada masyarakat. Adanya kebutuhan masyarakat tersebut, membuat penelitian ini bertujuan untuk memprediksi kepadatan suatu restoran satu jam kemudian. Didasari data survei dan data literatur yang ada, dengan metode simulasi dan juga analisis sistem yang dibangun menggunakan arsitektur kecerdasan buatan Feedforward Neural Network lalu dilatih dengan algoritma Backpropagation menghasilkan akurasi sebesar 97.8\% dengan data literatur.
\end{abstract}

Kata kunci: Kepadatan Restoran, Kecerdasan Buatan, Feedforward Neural Network, Time Series Forecasting.

Abstract
In this day and age, information about something is so important. The level of trust of modern society depends on the testing of information. Tested and accurate information will have a good impact on the community. One of the important but often missed information is information about the density of a restaurant. Information about restaurant density is important to know because it can affect the actions of someone who will visit the restaurant. This information is also useful to provide information in advance so that diners avoid full restaurants to avoid the spread of the Covid-19 virus, among other things. With limited operating hours as well as the number of restaurant visitors, information about the density of a restaurant becomes much needed. The lack of information on restaurant density is a major problem in the community. The needs of the community, made this study aims to predict the density of a restaurant an hour later. Based on survey data and existing literature data, with simulation methods and also system analysis built using feedforward neural network artificial intelligence architecture and then trained with Backpropagation algorithms produced an accuracy of $97.8 \%$ with literature data.

Keywords: Restaurant Density, Artificial Intelligence, Feedforward Neural Network, Time Series Forecasting.

\section{INTRODUCTION}

In this modern era, many emerging restaurant businesses from regional food to overseas. The rise of these restaurants is particularly prevalent in big cities (Richard, 2019). The emerging restaurants invite the appeal of the community because in addition to being a place to enjoy food restaurants are also often used to gather with friends. Besides, the existence of free WIFI service makes visitors feel at home lingering inside the restaurant resulting in a pile of restaurant visitors (Wardani, Jumain, \& Mufarihin, 2020). The appeal of visitors to the restaurant is very varied. From those who are willing to queue to reluctant to queue. Lack of information about the density of 
restaurants to go to can make visitors who are reluctant to queue and have already come to the restaurant feel disappointed (Fadhillah, Kharisma, \& Afirianto, 2020). As a result, diners have to look back for other restaurants. But it is very detrimental because it is also possible that the restaurant that suits the customer's wishes is far from the previous restaurant.

Solutions such as ordering food at restaurants using the delivery service can be used to avoid full restaurants and long wait times (Chen, $\mathrm{Hu}$, \& Wang, 2019). This service allows customers to simply stay in place and the service owner will deliver pre-ordered food. But sometimes this service has a fairly long estimated time and is not as expected (Chen et al., 2019). Factors such as traffic congestion and length of wait times in restaurants make the food ordered not following the estimated time (Chen et al., 2019). Again the same factor that is the density of restaurants is the cause of the precisely estimated time of delivery service. In obtaining restaurant density information, technology in the form of mobile phone applications combined with artificial intelligence is very useful for visitors to know the density of the intended restaurant. This technology can also be used to prevent crowds in public places to prevent the spread of the Covid-19 virus.

Public places such as restaurants have become the places where the pandemic is spreading quite high (Qian et al., 2020; Sexton \& Seaman, 2021), this is due to the needs of modern people who are accustomed to instant food. Based on these community needs, this study aims to help people in obtaining information on restaurant density to suppress the spread of pandemics. So in this case, we need a system to predict the state of a restaurant. In creating this system, artificial intelligence can be used to predict the state of a restaurant. By using existing data, artificial intelligence architecture, namely feedforward neural network, can easily be used to predict the density of a restaurant. After analyzing and conducting several simulations to predict the density of restaurants and get good results, the results of this system in the form of predicting restaurant density can be informed by various media to help the public in knowing the density of the intended restaurant.

In previous research (Fadhillah et al., 2020; Widjaya, Suryawan, \& Stefani, 2014), there is no research as currently researched, but there are few similarities between calculating many customers, mealtimes, and income. This research will be better because it focuses more on finding the condition of the restaurant that is density. Later the results of density can be developed to determine the number of people, time in line, income, and others. But the limited data and technology available make this research limited only to large restaurant restaurants and users who use android phones with the latest operating system.

\section{RESEARCH METHODS}

\section{Data Source}

Data obtained from a coffee shop in January of 2020. The data used is hourly visitor data from 7 a.m. to 9 p.m. Dataset can be seen at the link https://github.com/sayahsorangan/Resfo.

\section{Prediction System Design}

There are several parameters in determining the condition of a place, such as the parameters used in determining population density (area and number of residents in the area), or parameters used in determining road conditions (many vehicles, vehicle speed, vehicle type, road area, and others). These parameters are implemented according to the environment to be reviewed. Restaurants have characteristics that intersect with the characteristics of roads or residential areas. In restaurants, variables change not as fast on the road, but not as late as in residential areas. So that the combination of parameters of the two places is required.

The first parameter is the day of the week. Every day for example with numbers such as Monday (1), Tuesday (2), and so on until Sunday (7). This parameter is useful for seeing trends every day in restaurants. The second parameter is opening hours. According to the data obtained in the journal. Opening hours at the restaurant under review start from 9:00 to 21:00. Just like the first parameter, it's useful to see trends every hour.

The third parameter is the capacity of the restaurant. This is based on the lack of places in restaurants that can be occupied. This parameter is closely related to the area to calculate the density of the population, which in restaurants also affects the number of servings available each day. As the area affects the density of the area, the capacity of this restaurant is key to predicting the density of restaurants (Christiani, Tedjo, \& Martono, 2014; Thalib, 2018).

The fourth parameter is the number of diners in the restaurant. The number of visitors is the second most important parameter after capacity. This is because the number of visitors affects the density of restaurants such as the influence of vehicles on traffic, as well as the influence of the population on population density. These parameters may change over time (Christiani et al., 2014). 
JURNAL RISET INFORMATIKA

Vol. 3, No. 2 March 2021
P-ISSN: 2656-1743 |E-ISSN: 2656-1735

DOI: https://doi.org/10.34288/jri.v3i2.202
The fifth parameter for predicting restaurant density is the average time of diners inside the restaurant. These parameters act like the effect of speed on traffic flow. In the event of a buildup or the average time, a high diner eats will be more crowded the restaurant (Thalib, 2018).

Feedforward Neural Network architecture created using five perceptrons on the input layer. The first input is parameter one (restaurant capacity), second is parameter two (number of restaurant visitors), third is parameter 3 (average time of restaurant visitors). At the input layer, each parameter will be normalized to zero to one vulnerable, with the following calculations (Akshay Kumar \& Suresh, 2016; Auer, Burgsteiner, \& Maass, 2008; Benzer, 2015; Berno et al., 2003; Frean, 1990; Grossi \& Buscema, 2007; Hagan \& Menhaj, 1994; Razavi \& Tolson, 2011; Schmidt, Kraaijveld, \& Duin, 1992; Whitley \& Karunanithi, 1992; Wilamowski, 2011).

parameter $1=\frac{\text { day }-1}{7-1}$

parameter $2=\frac{\text { hour }-10}{21-10}$

parameter $3=\frac{\text { capasity }}{\text { capasity }}$

parameter $4=\frac{\text { people }}{\text { capasity }}$

parameter $5=\frac{\text { average time }}{120}$

In the hidden layer and output layer, the activation function to be used is the Sigmoid function, because the desired output is between zero and one. The sigmoid activation function can be calculated by the following formula.

$\operatorname{Sigmod}(x)=\frac{1}{1+e^{-x}}$

The second and third hidden layers will consist of five perceptrons, then the output layer consists of one perceptron. So that the entire architecture of the Feedforward Neural Network can be seen as follows.

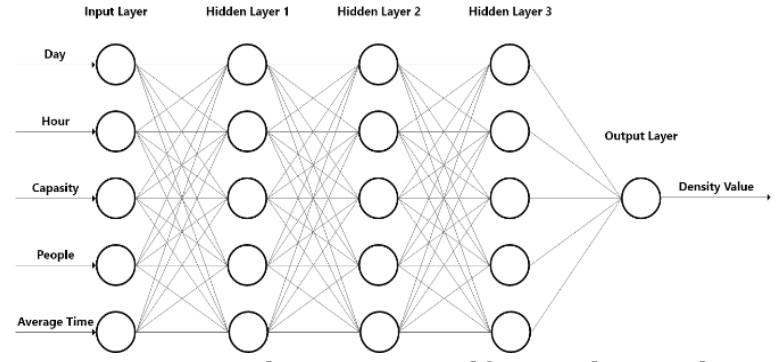

Figure 1. architecture Feedforward Neural Network.

This kind of architecture in Figure 1 is suitable because to predict things that change quickly, computing speed must be more important than good accuracy. But the expected accuracy is at least close to $80 \%$ to $90 \%$. The balance in terms of accuracy and computing speed in terms of artificial intelligence is usually counterintuitive.

The output of this Feedforward Neural Network architecture is between zero and one. Being vulnerable to certain values means the restaurant is empty, medium, full, or very full. Vulnerable values can be seen in table 1.

Tabel 1. Output Classification

\begin{tabular}{cc}
\hline Vulnerable Value & Restaurant Conditions \\
\hline Output $<=0.25$ & Empty \\
\hline $0.25>$ Output $<=0.50$ & Medium \\
\hline $0.50>$ Output $<=0.75$ & Full \\
\hline $0.75>$ Output $<=1$ & Very Full \\
\hline
\end{tabular}

Backpropagation is used to search for the best W (weights), or smallest errors. Backpropagation is run a million times to get error levels close to zero. The weights in the first iteration will be initialized with random values. The error value of the output desired with feedforward neural network results can be calculated by the Mean Square Error (MSE) formula as below.

$M S E=\frac{1}{n} \sum_{i=1}^{n}\left(h_{\theta}\left(x^{i}\right)-y^{i}\right)^{2}$.

So that after being trained with a variety of learning rate values, the following results are obtained.

Tabel 2. Error Every LR

\begin{tabular}{cccc}
\hline No & $\begin{array}{c}\text { Number of } \\
\text { Iterations }\end{array}$ & LR & $\begin{array}{c}\text { Best Error } \\
\text { Value (MSE) }\end{array}$ \\
\hline 1 & 1000000 & 0.1 & 0.001733699 \\
\hline 2 & 849117 & 0.2 & 0.001275407 \\
\hline 3 & 999999 & 0.3 & 0.000573247 \\
\hline 4 & 1000000 & 0.4 & 0.000526369 \\
\hline 5 & 1000000 & 0.5 & $4.52 \mathrm{E}-06$ \\
\hline 6 & 1000000 & 0.6 & 0.005735898 \\
\hline 7 & 999999 & 0.7 & 0.000115348 \\
\hline
\end{tabular}




\begin{tabular}{cccc}
\hline No & $\begin{array}{c}\text { Number of } \\
\text { Iterations }\end{array}$ & LR & $\begin{array}{c}\text { Best Error } \\
\text { Value (MSE) }\end{array}$ \\
\hline 8 & 780851 & 0.8 & 0.02747601 \\
\hline 9 & 1 & 0.9 & 0.113782659 \\
\hline 10 & 1 & 1 & 0.113782659 \\
\hline
\end{tabular}

Feedforward Neural Network relation with backpropagation results in smallest error value of 4.52E-06 in iteration to one million as in table 2. So the most suitable lr in training Feedforward Neural Network is 0.5 . The Weights value generated from lr 0.5 will be used in predicting restaurant density.

\section{Information Distribution Application Design}

This application modeling uses Unified Modelling Language (UML). UML contained in this application consists of a use case diagram, sequence diagram, and interface design.

In use case diagram, showing that the user can see the splash screen, information about the place, account information, application information, login, change password, create an account, and find a place. On the admin side, admins can do Create Update Read Delete (CURD) to user data, and place data.

The application will be started by opening Splash Screen. At the beginning of the application installed the application will check the internet access, and grant location access. If one of the accesses is not granted the application will stop running. If both accesses are granted the app will check if there is an active account or not. If there is an active account the view will be redirected to the Maps Menu, and otherwise, the view will be redirected to the Login Menu.

In the Login Menu, users can sign in using a previously created application account or a Google account by clicking on the Google logo. In this menu, users can also create an account by clicking on the words "Don't Have Account Yet?", after clicking the user will be redirected to the Registration menu. If the user clicks "Help" the user will be redirected to the Reset Password Menu. When the user clicks login, the user will be redirected to the Maps Menu if the account has been registered in the user database. Or when the user clicks on the Google logo, the app will pop-up the google account option to sign in.

In the Registration Menu, the user can create an account with the email that the user has. When the user registers, the email that the user input will be checked first whether it has previously been registered in the user database.

Reset Password menu is useful to change the password if the user forgets the password used. This menu will check if the email that the user input is registered by clicking on the Google logo or registration on the Registration menu. Accounts created by clicking on the Google logo do not require a password change, users can sign back in the same way. If the account is created by in-app registration, the application will send a password change link to the email to which the password will be changed.

Maps menu will give you a maps view like Google Maps. In this menu, users can search various places other than restaurants, but the data available in the application database is only a few restaurants. By writing the name of the restaurant place, the user will be given a pop-up in the form of information about the restaurant such as the address and density of the restaurant if the restaurant is listed in the application database.

The Profile menu will display the current account data to the user. In this menu, the user can change the account password by clicking "Reset Password". Users can also log out of the application by clicking on the logout, after which the user will be redirected to the login menu again.

User Interface is part of a website, software application, or hardware device that will interact directly with the user. This application is designed with a dark theme to make it more comfortable to see in the long term. This application has six User Interface designs namely Splash Screen design, Login Menu, Registration, Password Reset, Maps, and Profile. The User Interface design has been created in such a way as to facilitate the use of users in using the application. User Interface design uses Adobe Xd application and continued on Android Studio to arrange the look so that it looks like figure 2 .
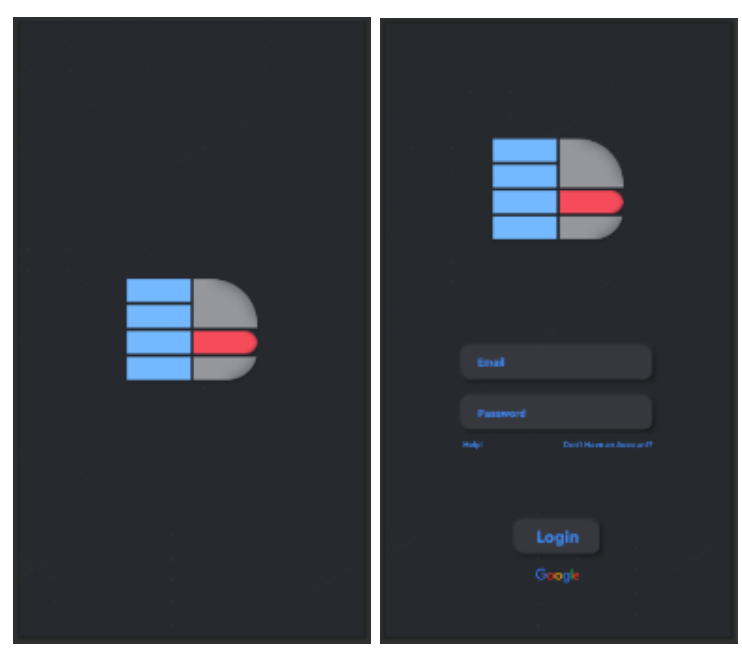
JURNAL RISET INFORMATIKA

Vol. 3, No. 2 March 2021

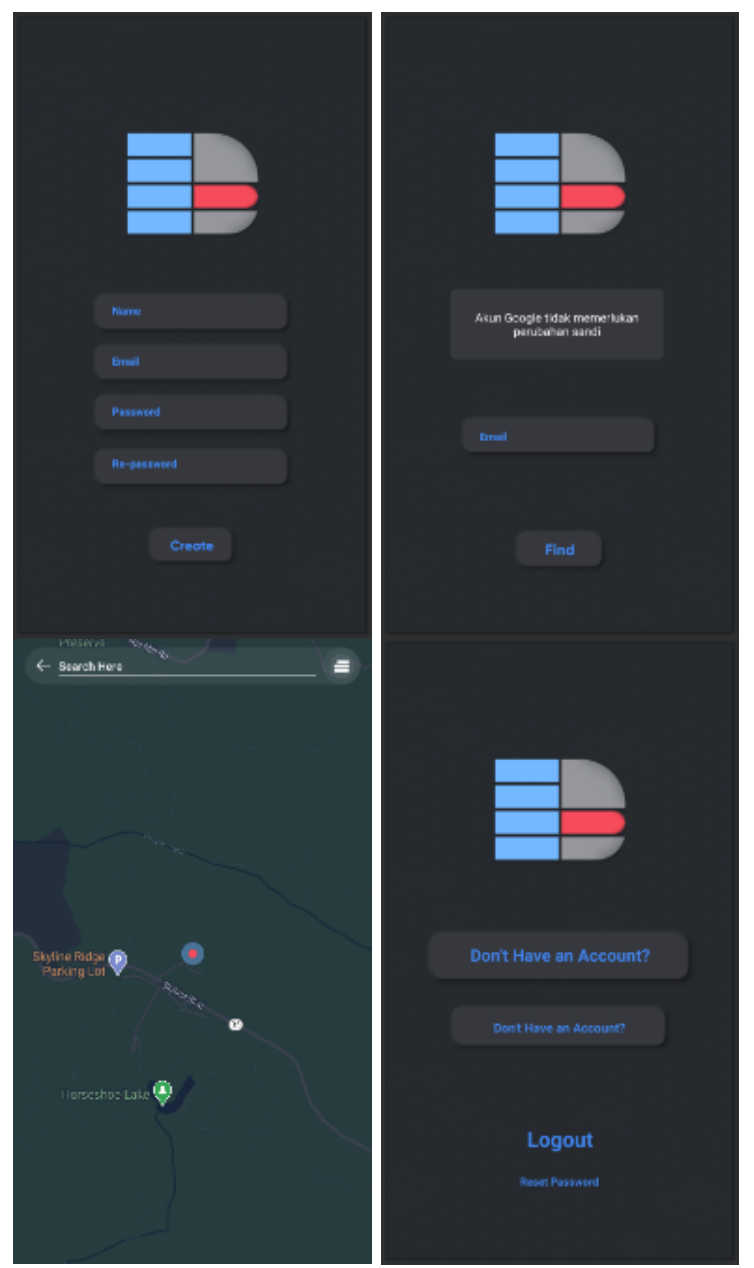

Figure 2. User Interface Application

This app will do two main things, namely getting the user's location from the phone's GPS to be processed in predicting restaurant density (Guo et al., 2019; Hegarty, 2017; Hlavacs \& Hummel, 2013; Vatansever \& Butun, 2017). Besides, this application will also be used as a means of conveying density information. With this kind of modeling, this application is expected to meet the needs of the community and be easy to use in daily activities.

\section{RESULTS AND DISCUSSION}

To test the floor plan system created with a latitude limit of -6.974700 to -6.975000 and longitude 107.629700 to 107.630000 . If within kilometers, the simulated area is $33.3 \times 33.3$ meters or $1108.89 \mathrm{~m} 2$. The map that has been prepared next is included the location of the restaurant with a light blue border. The restaurant is located at latitude coordinates -6.974800 to -6.974900 and longitude 107.629900 to 107.629800 . After that, the simulation begins by entering random coordinates in the restaurant environment map.
P-ISSN: 2656-1743 |E-ISSN: 2656-1735

DOI: https://doi.org/10.34288/jri.v3i2.202

Every five seconds the user coordinates will shift in a random direction with a latitude displacement distance and a longitude of 0.000001 multiplied by a random round number between -10 and 10. This adapts to unpredictable visitor behavior so that random numbers are used. User applications that are inside the light blue line area, will be colored red to indicate they are inside the restaurant, and the user outside will be given black. Every five seconds of the simulation is equal to 5 minutes in the real environment.

Coordinates of restaurant visitors in red will be used as a reference to be the value of system input. First, the system will calculate how many coordinates are dotted red. After that, the system will check how long the red dot is inside the light blue line. If there is a red dot that exits the light blue line, the coordinates will no longer be included in the calculation and will turn into a black dot. Similarly, if a black dot enters a light blue line, it will be a red dot, and be recalculated how long it will last in the light blue line.

Restaurant capacity parameters are entered directly into the database due to their unchanged value. The parameters of the number of visitors are obtained by calculating how many red dots on the simulation map. While the average visitor time parameter is obtained by finding the average time the red dot is inside the light blue line. From the results of a digital simulation run for 10 minutes, data obtained as follows in table 3.

Tabel 3. Inputs and System Results Based on Simulation Data

\begin{tabular}{|c|c|c|c|c|c|c|}
\hline No & $\mathrm{C}$ & $\mathbf{P}$ & AT & Den & Des & M\% \\
\hline 1 & 20 & 11 & 5 & 0.33 & $\mathrm{~S}$ & 0 \\
\hline 2 & 20 & 12 & 9.17 & 0.45 & $S$ & 0 \\
\hline 3 & 20 & 12 & 13.75 & 0.51 & $P$ & 100 \\
\hline 4 & 20 & 13 & 17.69 & 0.58 & $\mathrm{P}$ & 100 \\
\hline 5 & 20 & 12 & 22.92 & 0.59 & $\mathrm{P}$ & 100 \\
\hline 6 & 20 & 17 & 19.71 & 0.76 & SP & 100 \\
\hline 7 & 20 & 12 & 26.67 & 0.62 & $\mathrm{P}$ & 100 \\
\hline 8 & 20 & 9 & 34.44 & 0.62 & $\mathrm{P}$ & 100 \\
\hline 9 & 20 & 9 & 28.89 & 0.56 & $\mathrm{P}$ & 0 \\
\hline 10 & 20 & 10 & 30.5 & 0.61 & $\mathrm{P}$ & 100 \\
\hline 11 & 20 & 11 & 32.27 & 0.64 & $P$ & 100 \\
\hline 12 & 20 & 12 & 34.17 & 0.65 & $\mathrm{P}$ & 100 \\
\hline 13 & 20 & 10 & 42 & 0.67 & $\mathrm{P}$ & 100 \\
\hline 14 & 20 & 10 & 40.5 & 0.67 & $\mathrm{P}$ & 100 \\
\hline 15 & 20 & 12 & 38.33 & 0.67 & $\mathrm{P}$ & 100 \\
\hline 16 & 20 & 10 & 47.5 & 0.68 & $\mathrm{P}$ & 100 \\
\hline 17 & 20 & 8 & 56.88 & 0.67 & $\mathrm{P}$ & 100 \\
\hline 18 & 20 & 11 & 45.91 & 0.68 & $\mathrm{P}$ & 100 \\
\hline 19 & 20 & 11 & 50 & 0.68 & $\mathrm{P}$ & 100 \\
\hline 20 & 20 & 12 & 47.5 & 0.67 & $\mathrm{P}$ & 100 \\
\hline 21 & 20 & 13 & 47.69 & 0.67 & $\mathrm{P}$ & 100 \\
\hline 22 & 20 & 12 & 55 & 0.66 & $\mathrm{P}$ & 100 \\
\hline 23 & 20 & 11 & 61.82 & 0.66 & $\mathrm{P}$ & 100 \\
\hline 24 & 20 & 14 & 50 & 0.66 & $P$ & 100 \\
\hline 25 & 20 & 12 & 60 & 0.65 & $\mathrm{P}$ & 100 \\
\hline 26 & 20 & 12 & 53.75 & 0.67 & $\mathrm{P}$ & 100 \\
\hline
\end{tabular}


P-ISSN: 2656-1743 | E-ISSN: 2656-1735

DOI: https://doi.org/10.34288/jri.v3i2.202
JURNAL RISET INFORMATIKA

Vol. 3, No. 2 March 2021

\begin{tabular}{|c|c|c|c|c|c|c|}
\hline No & C & $\mathbf{P}$ & AT & Den & Des & M\% \\
\hline 27 & 20 & 12 & 55.83 & 0.66 & $\mathrm{P}$ & 100 \\
\hline 28 & 20 & 12 & 57.92 & 0.66 & $P$ & 100 \\
\hline 29 & 20 & 12 & 62.5 & 0.65 & $P$ & 100 \\
\hline 30 & 20 & 11 & 71.82 & 0.64 & $P$ & 100 \\
\hline 31 & 20 & 12 & 68.75 & 0.64 & $P$ & 100 \\
\hline 32 & 20 & 12 & 60.42 & 0.65 & $\mathrm{P}$ & 100 \\
\hline 33 & 20 & 10 & 59 & 0.67 & $P$ & 100 \\
\hline 34 & 20 & 9 & 62.78 & 0.67 & $\mathrm{P}$ & 100 \\
\hline 35 & 20 & 11 & 54.55 & 0.67 & $\mathrm{P}$ & 100 \\
\hline 36 & 20 & 11 & 58.64 & 0.67 & $P$ & 100 \\
\hline 37 & 20 & 11 & 53.64 & 0.67 & $\mathrm{P}$ & 100 \\
\hline 38 & 20 & 12 & 53.33 & 0.67 & $\mathrm{P}$ & 100 \\
\hline 39 & 20 & 12 & 56.67 & 0.66 & $\mathrm{P}$ & 100 \\
\hline 40 & 20 & 7 & 62.86 & 0.66 & $P$ & 100 \\
\hline 41 & 20 & 10 & 49 & 0.68 & $P$ & 100 \\
\hline 42 & 20 & 11 & 48.18 & 0.68 & $P$ & 100 \\
\hline 43 & 20 & 10 & 57 & 0.68 & $P$ & 100 \\
\hline 44 & 20 & 11 & 55.45 & 0.67 & $\mathrm{P}$ & 100 \\
\hline 45 & 20 & 13 & 50.38 & 0.66 & $\mathrm{P}$ & 100 \\
\hline 46 & 20 & 12 & 57.92 & 0.66 & $\mathrm{P}$ & 100 \\
\hline 47 & 20 & 10 & 72.5 & 0.65 & $P$ & 100 \\
\hline 48 & 20 & 10 & 77 & 0.65 & $\mathrm{P}$ & 100 \\
\hline 49 & 20 & 11 & 74.55 & 0.64 & $\mathrm{P}$ & 100 \\
\hline 50 & 20 & 10 & 86.5 & 0.66 & $P$ & 100 \\
\hline 51 & 20 & 13 & 65 & 0.64 & $P$ & 100 \\
\hline 52 & 20 & 9 & 91.67 & 0.69 & $P$ & 0 \\
\hline 53 & 20 & 10 & 87.5 & 0.66 & $P$ & 100 \\
\hline 54 & 20 & 12 & 77.92 & 0.63 & $\mathrm{P}$ & 100 \\
\hline 55 & 20 & 13 & 76.92 & 0.63 & $\mathrm{P}$ & 100 \\
\hline 56 & 20 & 14 & 76.43 & 0.63 & $P$ & 100 \\
\hline 57 & 20 & 14 & 81.07 & 0.64 & $P$ & 100 \\
\hline 58 & 20 & 13 & 91.15 & 0.67 & $\mathrm{P}$ & 0 \\
\hline 59 & 20 & 13 & 89.23 & 0.66 & $\mathrm{P}$ & 100 \\
\hline 60 & 20 & 14 & 87.86 & 0.66 & $P$ & 100 \\
\hline 61 & 20 & 12 & 103.75 & 0.76 & SP & 100 \\
\hline 62 & 20 & 12 & 108.75 & 0.8 & SP & 100 \\
\hline 63 & 20 & 12 & 102.08 & 0.74 & $P$ & 0 \\
\hline 64 & 20 & 13 & 98.85 & 0.72 & $\mathrm{P}$ & 0 \\
\hline 65 & 20 & 11 & 109.55 & 0.8 & SP & 100 \\
\hline 66 & 20 & 12 & 102.5 & 0.75 & $\mathrm{P}$ & 0 \\
\hline 67 & 20 & 11 & 115.91 & 0.85 & SP & 100 \\
\hline 68 & 20 & 14 & 95.71 & 0.7 & $\mathrm{P}$ & 0 \\
\hline 69 & 20 & 14 & 100 & 0.74 & $\mathrm{P}$ & 0 \\
\hline 70 & 20 & 14 & 105 & 0.77 & SP & 100 \\
\hline 71 & 20 & 15 & 79.67 & 0.65 & $\mathrm{P}$ & 100 \\
\hline 72 & 20 & 13 & 95 & 0.69 & $P$ & 0 \\
\hline 73 & 20 & 12 & 107.5 & 0.79 & SP & 100 \\
\hline 74 & 20 & 14 & 97.14 & 0.71 & $P$ & 0 \\
\hline 75 & 20 & 14 & 102.14 & 0.75 & $\mathrm{P}$ & 0 \\
\hline 76 & 20 & 13 & 95.77 & 0.7 & $\mathrm{P}$ & 0 \\
\hline 77 & 20 & 11 & 115.45 & 0.85 & SP & 100 \\
\hline 78 & 20 & 13 & 102.69 & 0.75 & $\mathrm{P}$ & 0 \\
\hline 79 & 20 & 12 & 115.83 & 0.85 & SP & 100 \\
\hline 80 & 20 & 13 & 111.92 & 0.82 & SP & 100 \\
\hline 81 & 20 & 14 & 108.93 & 0.81 & SP & 100 \\
\hline 82 & 20 & 14 & 112.86 & 0.83 & SP & 100 \\
\hline 83 & 20 & 13 & 120 & 0.88 & SP & 100 \\
\hline 84 & 20 & 13 & 120 & 0.88 & SP & 100 \\
\hline 85 & 20 & 13 & 120 & 0.88 & SP & 100 \\
\hline 86 & 20 & 14 & 120 & 0.88 & SP & 100 \\
\hline 87 & 20 & 14 & 120 & 0.88 & SP & 100 \\
\hline 88 & 20 & 13 & 120 & 0.88 & SP & 100 \\
\hline 89 & 20 & 13 & 120 & 0.88 & SP & 100 \\
\hline 90 & 20 & 12 & 120 & 0.88 & SP & 100 \\
\hline 91 & 20 & 14 & 120 & 0.88 & SP & 100 \\
\hline 92 & 20 & 15 & 120 & 0.88 & SP & 100 \\
\hline
\end{tabular}

\begin{tabular}{ccccccc}
\hline No & C & P & AT & Den & Des & M\% \\
\hline 93 & 20 & 13 & 120 & 0.88 & SP & 100 \\
\hline 94 & 20 & 13 & 120 & 0.88 & SP & 100 \\
\hline 95 & 20 & 13 & 120 & 0.88 & SP & 100 \\
\hline 96 & 20 & 15 & 120 & 0.88 & SP & 100 \\
\hline 97 & 20 & 14 & 120 & 0.88 & SP & 100 \\
\hline 98 & 20 & 14 & 120 & 0.88 & SP & 100 \\
\hline 99 & 20 & 14 & 120 & 0.88 & SP & 100 \\
\hline 100 & 20 & 14 & 120 & 0.88 & SP & 100 \\
\hline 101 & 20 & 13 & 120 & 0.88 & SP & 100 \\
\hline 102 & 20 & 13 & 120 & 0.88 & SP & 100 \\
\hline 103 & 20 & 13 & 120 & 0.88 & SP & 100 \\
\hline 104 & 20 & 12 & 120 & 0.88 & SP & 100 \\
\hline 105 & 20 & 10 & 120 & 0.88 & SP & 100 \\
\hline 106 & 20 & 12 & 120 & 0.88 & SP & 100 \\
\hline 107 & 20 & 12 & 120 & 0.88 & SP & 100 \\
\hline 108 & 20 & 13 & 120 & 0.88 & SP & 100 \\
\hline 109 & 20 & 10 & 120 & 0.88 & SP & 100 \\
\hline 110 & 20 & 14 & 120 & 0.88 & SP & 100 \\
\hline 111 & 20 & 16 & 120 & 0.87 & SP & 100 \\
\hline 112 & 20 & 15 & 120 & 0.88 & SP & 100 \\
\hline 113 & 20 & 16 & 120 & 0.87 & SP & 100 \\
\hline 114 & 20 & 15 & 120 & 0.88 & SP & 100 \\
\hline 115 & 20 & 15 & 120 & 0.88 & SP & 100 \\
\hline 116 & 20 & 14 & 120 & 0.88 & SP & 100 \\
\hline 117 & 20 & 14 & 120 & 0.88 & SP & 100 \\
\hline 118 & 20 & 13 & 120 & 0.88 & SP & 100 \\
\hline 119 & 20 & 13 & 120 & 0.88 & SP & 100 \\
\hline 120 & 20 & 15 & 120 & 0.88 & SP & 100 \\
\hline & & Average Matches & & & 87.5 \\
\hline & & & & & & \\
\hline
\end{tabular}

From table 3 the density value can be based only on simulations that are in such a way as to be identical to the original environment. The match rate between the system output and the respondent classification reaches $87.5 \%$, which means that the system is possible to be developed further. For the prediction test, the journal entitled Restaurant Revenue Management (Studi Kasus Restoran Xx Ngaliyan Semarang) obtained data such as the table below in table 4 (Fuadillah \& Suliantoro, 2016).

Tabel 4. Percentage Data of Filled Capacity

\begin{tabular}{cccccccc}
\hline Ho & Mo & Tu & We & Th & Fr & Sa & Su \\
\hline 10 & 3 & 3 & 3 & 3 & 3 & 2 & 1 \\
\hline 11 & 17 & 16 & 17 & 16 & 16 & 10 & 6 \\
\hline 12 & 43 & 42 & 43 & 43 & 28 & 17 & 10 \\
\hline 13 & 59 & 54 & 55 & 57 & 43 & 18 & 12 \\
\hline 14 & 39 & 36 & 36 & 35 & 57 & 28 & 18 \\
\hline 15 & 24 & 24 & 23 & 21 & 31 & 24 & 18 \\
\hline 16 & 15 & 15 & 15 & 14 & 14 & 13 & 8 \\
\hline 17 & 16 & 14 & 14 & 15 & 15 & 10 & 3 \\
\hline 18 & 17 & 13 & 16 & 14 & 16 & 18 & 3 \\
\hline 19 & 24 & 23 & 25 & 23 & 23 & 32 & 20 \\
\hline 20 & 9 & 9 & 9 & 10 & 10 & 14 & 16 \\
\hline 21 & 1 & 1 & 1 & 1 & 1 & 3 & 1 \\
\hline 22 & 0 & 0 & 0 & 0 & 0 & 0 & 0 \\
\hline
\end{tabular}

The journal also obtained data on the average length of visitors in the restaurant is 54 minutes 36 seconds. So that the data obtained 
JURNAL RISET INFORMATIKA

Vol. 3, No. 2 March 2021

restaurant density based on the classification determined by respondents as table 5 .

Table 5. Restaurant Density Data According to Respondent Classification

\begin{tabular}{cccccccc}
\hline Ho & Mo & Tu & We & Th & Fr & Sa & Su \\
\hline 10 & M & M & M & M & M & M & M \\
\hline 11 & M & M & M & M & M & M & M \\
\hline 12 & F & F & F & F & F & M & M \\
\hline 13 & F & F & F & F & F & M & M \\
\hline 14 & $\mathrm{~F}$ & F & F & F & F & F & M \\
\hline 15 & $\mathrm{M}$ & $\mathrm{M}$ & $\mathrm{M}$ & $\mathrm{M}$ & $\mathrm{F}$ & $\mathrm{M}$ & $\mathrm{M}$ \\
\hline 16 & $\mathrm{M}$ & $\mathrm{M}$ & $\mathrm{M}$ & $\mathrm{M}$ & $\mathrm{M}$ & $\mathrm{M}$ & $\mathrm{M}$ \\
\hline 17 & $\mathrm{M}$ & $\mathrm{M}$ & $\mathrm{M}$ & $\mathrm{M}$ & $\mathrm{M}$ & $\mathrm{M}$ & $\mathrm{M}$ \\
\hline 18 & $\mathrm{M}$ & $\mathrm{M}$ & $\mathrm{M}$ & $\mathrm{M}$ & $\mathrm{M}$ & $\mathrm{M}$ & $\mathrm{M}$ \\
\hline 19 & $\mathrm{M}$ & $\mathrm{M}$ & $\mathrm{M}$ & $\mathrm{M}$ & $\mathrm{M}$ & $\mathrm{F}$ & $\mathrm{M}$ \\
\hline 20 & $\mathrm{M}$ & $\mathrm{M}$ & $\mathrm{M}$ & $\mathrm{M}$ & $\mathrm{M}$ & $\mathrm{M}$ & $\mathrm{M}$ \\
\hline 21 & $\mathrm{M}$ & $\mathrm{M}$ & $\mathrm{M}$ & $\mathrm{M}$ & $\mathrm{M}$ & $\mathrm{M}$ & $\mathrm{M}$ \\
\hline 22 & $\mathrm{E}$ & $\mathrm{E}$ & $\mathrm{E}$ & $\mathrm{E}$ & $\mathrm{E}$ & $\mathrm{E}$ & $\mathrm{E}$ \\
\hline
\end{tabular}

The data is used as system input to predict. The predicted result of the system from the data input is as in table 6 .

Tabel 6. System Output Based on Original Data

\begin{tabular}{cccccccc}
\hline Ho & Mo & Tu & We & Th & Fr & Sa & Su \\
\hline 10 & M & M & M & M & M & M & M \\
\hline 11 & M & M & M & M & M & M & M \\
\hline 12 & F & F & F & F & M & M & M \\
\hline 13 & F & F & F & F & F & M & M \\
\hline 14 & $\mathrm{~F}$ & $\mathrm{~F}$ & $\mathrm{~F}$ & $\mathrm{~F}$ & $\mathrm{~F}$ & $\mathrm{M}$ & $\mathrm{M}$ \\
\hline 15 & $\mathrm{M}$ & $\mathrm{M}$ & $\mathrm{M}$ & $\mathrm{M}$ & $\mathrm{F}$ & $\mathrm{M}$ & $\mathrm{M}$ \\
\hline 16 & $\mathrm{M}$ & $\mathrm{M}$ & $\mathrm{M}$ & $\mathrm{M}$ & $\mathrm{M}$ & $\mathrm{M}$ & $\mathrm{M}$ \\
\hline 17 & $\mathrm{M}$ & $\mathrm{M}$ & $\mathrm{M}$ & $\mathrm{M}$ & $\mathrm{M}$ & $\mathrm{M}$ & $\mathrm{M}$ \\
\hline 18 & $\mathrm{M}$ & $\mathrm{M}$ & $\mathrm{M}$ & $\mathrm{M}$ & $\mathrm{M}$ & $\mathrm{M}$ & $\mathrm{M}$ \\
\hline 19 & $\mathrm{M}$ & $\mathrm{M}$ & $\mathrm{M}$ & $\mathrm{M}$ & $\mathrm{M}$ & $\mathrm{F}$ & $\mathrm{M}$ \\
\hline 20 & $\mathrm{M}$ & $\mathrm{M}$ & $\mathrm{M}$ & $\mathrm{M}$ & $\mathrm{M}$ & $\mathrm{M}$ & $\mathrm{M}$ \\
\hline 21 & $\mathrm{M}$ & $\mathrm{M}$ & $\mathrm{M}$ & $\mathrm{M}$ & $\mathrm{M}$ & $\mathrm{M}$ & $\mathrm{M}$ \\
\hline 22 & $\mathrm{E}$ & $\mathrm{E}$ & $\mathrm{E}$ & $\mathrm{E}$ & $\mathrm{E}$ & $\mathrm{E}$ & $\mathrm{E}$ \\
\hline
\end{tabular}

From input data as many as 91 conditions, the system predicts 89 conditions correctly or the suitability of the system with the original data reaches 97.8. Next, to test the application, beta testing is used to see application performance. Apps are shared through questionnaires and users review app performance, and views. the results of beta testing areas table 7 .

Table 7. List of Questions

\begin{tabular}{ll}
\hline No & \multicolumn{1}{c}{ Question } \\
\hline 1 & $\begin{array}{l}\text { Is the Restaurant Density Prediction app } \\
\text { convenient to use? }\end{array}$ \\
\hline
\end{tabular}

P-ISSN: 2656-1743 |E-ISSN: 2656-1735

DOI: https://doi.org/10.34288/jri.v3i2.202

\begin{tabular}{cl}
\hline 2 & $\begin{array}{l}\text { Can the information displayed in the } \\
\text { Restaurant Density Prediction app be } \\
\text { captured easily and clearly? }\end{array}$ \\
\hline 3 & $\begin{array}{l}\text { Is the help feature in the Restaurant Density } \\
\text { Prediction app helpful? }\end{array}$ \\
\hline 4 & $\begin{array}{l}\text { Does the Restaurant Density Prediction app } \\
\text { fit the user's needs? }\end{array}$ \\
\hline 5 & $\begin{array}{l}\text { Is the display on the Restaurant Density } \\
\text { Prediction app comfortable to look at? }\end{array}$ \\
\hline 6 & $\begin{array}{l}\text { Are menu views, features, and symbols in } \\
\text { the Restaurant Density Prediction app easy } \\
\text { to spot? }\end{array}$ \\
\hline 7 & $\begin{array}{l}\text { Is the font size displayed in the Restaurant } \\
\text { Density Prediction app easy to read? }\end{array}$ \\
\hline 8 & $\begin{array}{l}\text { Is the "create account" and "login" process } \\
\text { easy to use? }\end{array}$ \\
\hline
\end{tabular}

from the list of questions above, the respondents' responses are as follows.

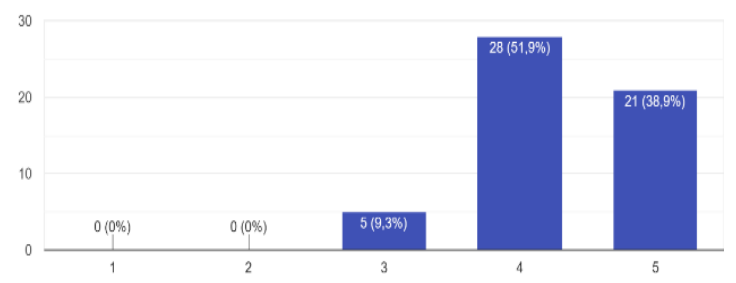

Figure 3. Question 1

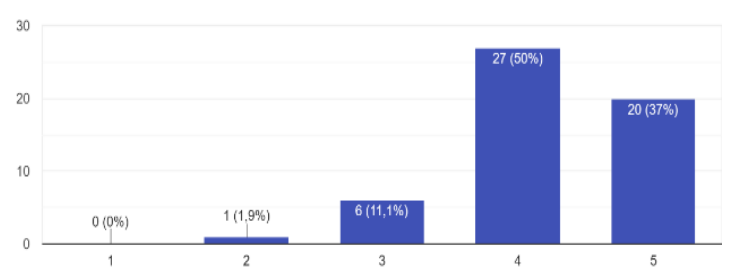

Figure 4. Question 2

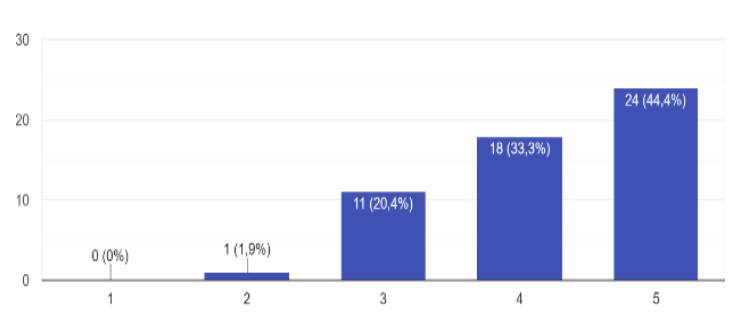

Figure 5. Question 3

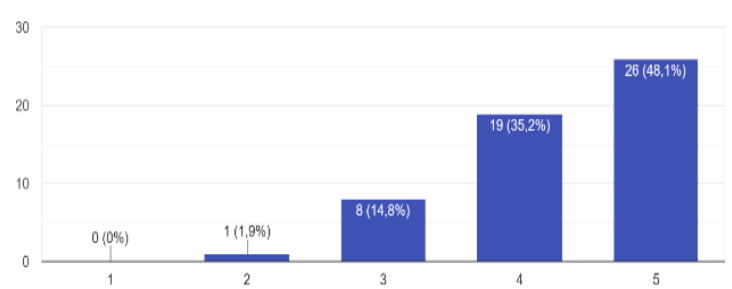

Figure 6. Question 4 


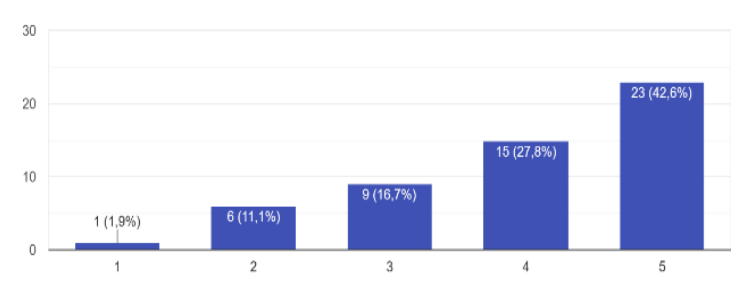

Figure 7. Question 5

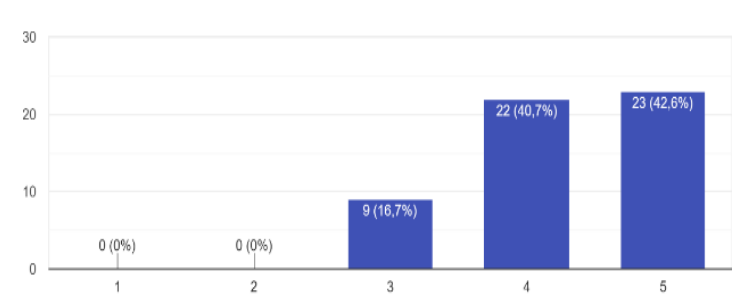

Figure 8. Question 6

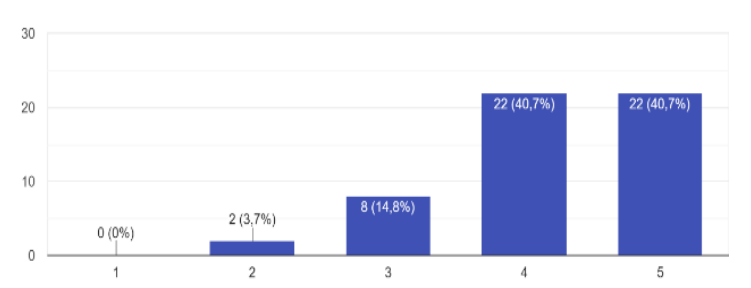

Figure 9. Question 7

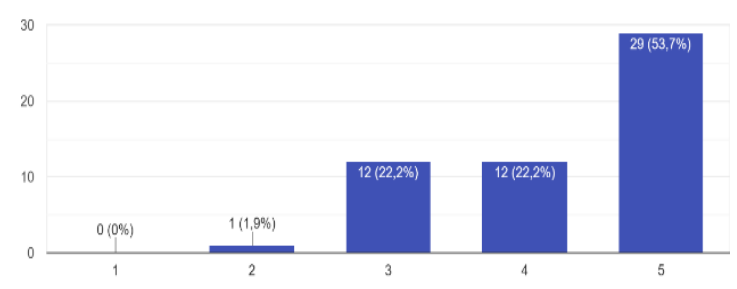

Figure 10. Question 8

From each of these questions the result from the respondent's is in figure 3 and so on until figure 10, the higher the value the better the respondent's assessment of this application. But some respondents rated low on question number five about the appearance of the interface. This may be based on respondents who are not very comfortable using dark mode. Some respondents also rated poorly on the size and color of letters that were a little difficult to read on question number seven. But overall, the app is welcomed by the community. From the results above, this research may still be very early and should be developed further, such as making applications that can be more optimization, and the use of other parameters in the contradiction. More datasets can make this system better. The lack of accurate mapping technology makes the accuracy of density determinants decrease. This system will be excellent when combined with a 3D positioning system. Unfortunately, 3 Dimension positioning system is difficult to implement with various factors.

\section{CONCLUSIONS AND SUGGESTIONS}

\section{Conclusions}

Feedforward Neural Network is quite good for predicting restaurant density with FSF method, by using adam optimizer and relu activation function, Feedforward Neural Network can match output with existing data with an MSE value of $7.585 \mathrm{e}-06$ and a test MSE value of 0 . 006923. The mobile application of restaurant density information can be built with Java programming language as well as some additional APIs such as Place API, Firebase API, etc. The design of the adobe $\mathrm{Xd}$ interface is very easy to elaborate on in setting up the interface to be used in the application. this application is welcomed in the community, proven by good assessment obtained from respondents' reviews. based on the above, the purpose of the research to provide information on restaurant density has been achieved by the application of restaurant density information and a restaurant density prediction system.

\section{Suggestions}

Using other neural network architectures to predict restaurant density such as RNN, or can use other optimization functions and other activation functions such as sigmoid. Restaurant density information applications can be created also in other operating systems such as iOS. Added normal mode to better cover users who are not very comfortable with dark mode. Add color and writebased settings to the app.

\section{REFERENCES}

Akshay Kumar, H., \& Suresh, Y. (2016). Multilayer feed-forward neural network to predict the speed of the wind. 2016 International Conference on Computation System and Information Technology for Sustainable Solutions, CSITSS 2016, 285-290. https://doi.org/10.1109/CSITSS.2016.77793 72

Auer, P., Burgsteiner, H., \& Maass, W. (2008). A learning rule for very simple universal approximators consisting of a single layer of perceptrons. Neural Networks, 21(5), 786795.

https://doi.org/10.1016/j.neunet.2007.12.0 36

Benzer, R. (2015). Population dynamics forecasting using artificial neural networks. Fresenius Environmental Bulletin, 24(2), 460-466. 
Berno, E., Brambilla, L., Canaparo, R., Casale, F., Costa, M., Della Pepa, C., ... Pasero, E. (2003). Application of Probabilistic Neural Networks to Population Pharmacokinetics. Proceedings of the International Joint Conference on Neural Networks, 4(I), 2637-2642. https://doi.org/10.1109/ijcnn.2003.122398 3

Chen, M., Hu, M., \& Wang, J. (2019). Food Delivery Service and Restaurant: Friend or Foe? SSRN Electronic https://doi.org/10.2139/ssrn.3469971

Christiani, H., Tedjo, P., \& Martono, B. (2014). Analisis Dampak Kepadatan Penduduk Terhadap Kualitas Hidup Masyarakat Provinsi Jawa Tengah. Serat Acitya, 3(1), 102114. Retrieved from http://jurnal.untagsmg.ac.id/index.php/sa/a rticle/view/125

Fadhillah, G. D., Kharisma, A. P., \& Afirianto, T. (2020). Pengembangan RestoCrowd: Aplikasi Android Penghitung Jumlah Pengunjung Restoran Berbasis Crowdsourcing dengan Ekstrapolasi. Jurnal Pengembangan Teknologi Informasi Dan Ilmu Komputer, 4(4), 10421047.

Frean, M. (1990). The Upstart Algorithm: A Method for Constructing and Training Feedforward Neural Networks. Neural Computation, 2(2), 198-209.

https://doi.org/10.1162/neco.1990.2.2.198

Fuadillah, E. A., \& Suliantoro, H. (2016). Restaurant Revenue Management (Studi Kasus Restoran XX Ngaliyan Semarang). Industrial Engineering Online Journal, 5(1), 1-10. Retrieved from https://ejournal3.undip.ac.id/index.php/ieoj /article/view/10654

Grossi, E., \& Buscema, M. (2007). Introduction to Artificial Neural Networks (ANN). European Journal of Gastroenterology \& Hepatology, 19(12), 1046-1054. https://doi.org/10.1097/MEG.0b013e3282f $198 \mathrm{a} 0$

Guo, G., Chen, R., Ye, F., Peng, X., Liu, Z., \& Pan, Y. (2019). Indoor Smartphone Localization: A Hybrid WiFi RTT-RSS Ranging Approach. IEEE Access, 7, 176767-176781. https://doi.org/10.1109/ACCESS.2019.2957 753

Hagan, M. T., \& Menhaj, M. B. (1994). Training Feedforward Networks with the Marquardt Algorithm. IEEE Transactions on Neural Networks, 5(6), 989-993. https://doi.org/10.1109/72.329697

Hegarty, C. J. (2017). The Global Positioning System (GPS). In P. J. G. Teunissen \& O. Montenbruck
(Eds.), Springer Handbook of Global Navigation Satellite Systems (Vol. 50, pp. 197218). Switzerland: Springer International Publishing. https://doi.org/https://doi.org/10.1007/97 8-3-319-42928-1

Hlavacs, H., \& Hummel, K. A. (2013). Cooperative positioning when using local position information: Theoretical framework and error analysis. IEEE Transactions on Mobile Computing, 12(10), 2091-2104. https://doi.org/10.1109/TMC.2012.197

Qian, H., Miao, T., Liu, L., Zheng, X., Luo, D., \& Li, Y. (2020). Indoor transmission of SARS-CoV-2. Indoor Air. https://doi.org/10.1111/ina.12766

Razavi, S., \& Tolson, B. A. (2011). A new formulation for feedforward neural networks. IEEE Transactions on Neural Networks, 22(10), 1588-1598. https://doi.org/10.1109/TNN.2011.216316 9

Richard, M. (2019). Bisnis Restoran Cepat Saji Berpeluang Tumbuh 15\% Tahun Ini. Retrieved from Bisnis Indonesia website: https://ekonomi.bisnis.com/read/20190211 /12/887488/bisnis-restoran-cepat-sajiberpeluang-tumbuh-15-tahun-ini

Schmidt, W. F., Kraaijveld, M. A., \& Duin, R. P. W. (1992). Feed Forward Neural Networks With Random Weights. International Conference on Pattern Recognition, 1-4. IEEE Computer Society Press.

Sexton, J., \& Seaman, J. (2021). Despite reopening, restaurants still "high risk" for spreading COVID-19, experts say. Retrieved from denverpost.com website: https://www.denverpost.com/2021/02/12/ colorado-restaurants-covid-transmission/

Thalib, M. T. N. (2018). Analisis Hubungan Volume, Kecepatan, Dan Kepadatan Arus Lalu Lintas Pada Ruas Jalan Prof. Dr. H.B. Jassin Dengan Membandingkan Metode Greenshielddan Metode Greenberg. RADIAL -JuRnal PerADaban SaIns, RekayAsa Dan TeknoLogi, 6(1), 59-68. Retrieved from https://stitekbinataruna.ejournal.id/radial/article/view/165

Vatansever, S., \& Butun, I. (2017). A broad overview of GPS fundamentals: Now and future. 2017 IEEE 7th Annual Computing and Communication Workshop and Conference, CCWC 2017. https://doi.org/10.1109/CCWC.2017.78683 73

Wardani, I., Jumain, J., \& Mufarihin, M. (2020). Pengaruh Harga, Free Wifi Dan Fasilitas 
Terhadap Kepuasan Pelanggan Pada Kedai Coffee JMP Pahlawan Lamongan. Jurnal Media Komunikasi Ilmu Ekonomi, 35(2), 1-12. Retrieved from https://ejournal.stiekhad.id/index.php/mela ti/article/view/15

Whitley, D., \& Karunanithi, N. (1992). Generalization in feed forward neural networks. Proceedings. IJCNN - International Joint Conference on Neural Networks, 77-82. https://doi.org/10.1109/ijcnn.1991.155316

Widjaya, O. H., Suryawan, I. N., \& Stefani, S. (2014).
Analisis Pengaruh Waktu Tunggu, Harga, Kualitas Terhadap Kepuasan Pelanggan Dan Loyalitas Pelanggan "R" Seafood. SNIT 2014, B18-B25. Jakarta: LPPM Bina Sarana Inforatika. Retrieved from http://seminar.bsi.ac.id/snit/ind ex.php/snit2014/article/view/355

Wilamowski, B. M. (2011). How to not get frustrated with neural networks. Proceedings of the IEEE International Conference on Industrial Technology, (December), 5-11. https://doi.org/10.1109/ICIT.2011.5754336 